\title{
Hodgkin's Lymphoma: Epidemiological Clinical Characteristics in a Reference Hospital in Oncology in the Eastern Amazon.
}

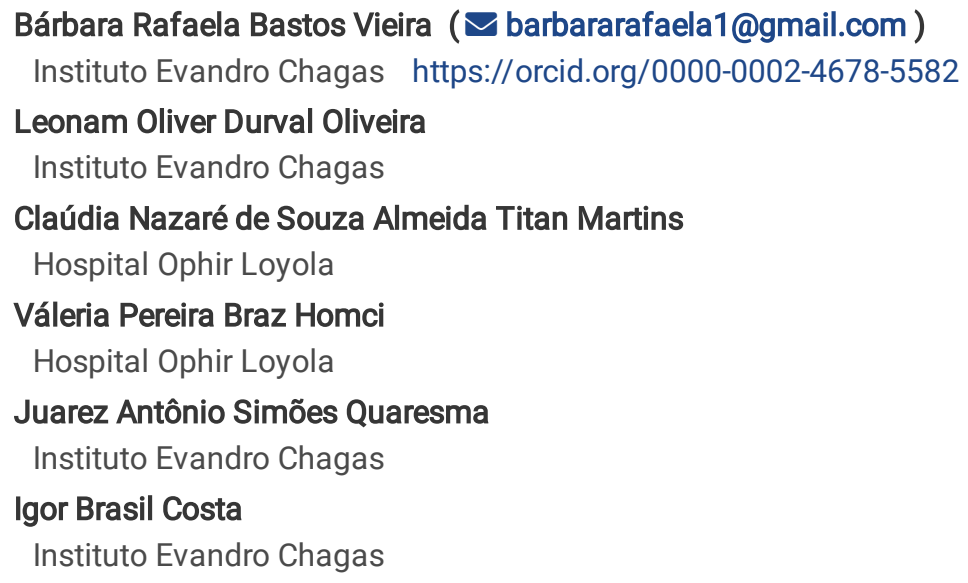




\section{Abstract}

Background: Lymphomas are a type of cancer that starts in the lymphatic system. This system is made up of organs, tissues and vessels responsible for immune function. Hodgkin's lymphoma is characterized by giant cells, well differentiated and binucleated. It is divided into two groups: classical hodgkin's lymphoma and hodgkin's lymphoma predominant in nodular lymphocytes. The classic in turn is subdivided into four more histological subtypes: nodular sclerosis, rich in lymphocytes, depleted in lymphocytes and mixed cellularity. This study analyzed the spatial distribution and clinical-epidemiological and Hodgkin's lymphoma characteristics and their histological types in patients diagnosed with the disease at a Reference Hospital in Oncology in the Eastern Amazon between the years 2006 to 2015.

Methods: A study was carried out cross-sectional, retrospective, analytical and descriptive study through the analysis of the medical records of 336 patients diagnosed with the disease in that given period and location, the $\mathrm{G}$ test was performed to demonstrate the association between the variables.

Results: The cases of Hodgkin's Lymphoma came from the following Brazilian states: Pará (318 cases), Amapá (15 cases), Maranhão (2 cases), Piauí (1 case). It affected more men (62\%) and young adults (mean age 26 years). The most frequent histological type was nodular sclerosis (65\%). The primary location of the tumor was predominant in the cervical lymph nodes (65\%). Mostly, patients with no metastases (98\%), but the presence of metastases was more frequent in Hodgkin's lymphoma, Nodular Lymphocytic Predominance (18\%).

Conclusion: The data obtained in this study allow to know some regional peculiarities about Hodgkin's Lymphoma, which can contribute to regional preventive policies, as well as can support comparisons about the disease in other regions, contributing to better understand the heterogeneity of LH.

\section{Background}

The Hodgkin's disease, as it was called, was first described in 1832 by the British pathologist Thomas Hodgkin, when he performed the autopsy of patients affected by lymphadenopathy and splenomegaly (1). In 1999, the pathologists recognized that Hodgkin's disease was a proliferative clonal B-cell disease, modifying the term to Hodgkin's Lymphoma (HL) (2).

According to the World Health Organization and based on morphology and immunohistochemistry, $\mathrm{HL}$ is classified into two major type: classical HL (cHL) and Nodular Lymphocyte-Predominant Hodgkin's Lymphoma (NLPHL), accounting for 95\% and 5\% of all HL cases, respectively (3). The $\mathrm{CHL}$ is further subdivided four histological types: Nodular Sclerosis Hodgkin's Lymphoma (NSHL); Mixed Cellularity Hodgkin's Lymphoma (MCHL); Lymphocyte-Rich Hodgkin's Lymphoma (LRHL); Lymphocyte-Depleted Hodgkin's Lymphoma (LDHL) (4).

Most HL patients feature common symptoms, such as lymphadenopathy, high fever, night sweats, and profound weight loss; some patients can also feature chronic pruritus (5). The HL oncogenesis is unclear; however, viral infections exposition, hereditary factors, and immunosuppression are high-risk factors associated with $\mathrm{HL}$ developing (6).

$\mathrm{HL}$ is most frequent in adolescents and young adults, but it can occur at any age. HL tumors usually involve lymph nodes, but it can also affect extranodal sites like the spleen, liver, lungs, and bone marrow (7).

In Brazil, the expected number of HL new cases - for each year of triennium 2020-2022 - will be of 1,590 cases for men and 1,050 cases for women. These values correspond to an estimated risk of 1.52 cases per 100,000 men and 0.95 cases per 100,000 women. In 2017, there were 355 deaths caused by $\mathrm{HL}$ in Brazil. $\mathrm{HL}$ is the $12^{\circ}$ most common type of cancer in Brazil's Northern region (1.05/100.000). (8).

The $\mathrm{HL}$ and its histological types have shown a heterogeneous character, which can vary due to several factors such as the level of development of the region and the affected population. Thus, in the region of this study, little is known about the clinical epidemiological characteristics, and the spatial distribution of LH and its histological types. Thus, this study aimed to analyze these characteristics and the spatial distribution of the disease in a Reference Hospital in Oncology in the Eastern Amazon.

\section{Methods}

A retrospective, analytical, and descriptive cross-sectional study was conducted. The cases studied were composed of patients diagnosed with Hodgkin's Lymphoma at a reference hospital in eastern Amazon, the Ophir Loyola Hospital (OLH). The OLH is accredited as a Center of High Complexity in Oncology (CACON) and serves as the main reference of the health network for diagnoses and cancer treatments in the state of Pará (9). 
The medical records were analyzed to determine the clinicopathological features and spatial distribution of patients. This study was approved by the Research Ethics Committee of Evandro Chagas Institute (CAAE 92116618.0.0000.0019) and Ophir Loyola Hospital (CAAE 92116618.0.3001.5550).

All patients with HL diagnosed by histopathology at Ophir Loyola Hospital - between 2006 and 2015 - were included; these patients were of both sexes, from all ages and backgrounds. Initially, $415 \mathrm{HL}$ cases were identified for study analysis, but 79 were excluded due to incomplete clinical data such as absence of histological type. Thus, $336 \mathrm{HL}$ cases were included in this study.

The medical records of patients were analyzed at the Hospital Cancer Registry and Medical Archive Division of Ophir Loyola Hospital. The following variables were obtained: age (discrete quantitative), gender (dichotomous), histopathological diagnosis, ethnicity (Brazilian Institute of Geography and Statistics classification), family history of cancer, alcohol and/or tobacco consumption, primary tumor location and presence of metastasis at the beginning of treatment, that is, when there is dissemination in at least one organ outside the lymphatic system. Information on metastasis in medical records was defined by medical analysis using standard diagnostic assistance methods (clinical evaluation, X-ray, computed tomography, magnetic resonance, bone scintigraphy, PET-CT)

The descriptive statistics was performed according to the frequency analysis of histological types, considering the following variables: age, gender, family history of cancer, alcohol and/or tobacco consumption, primary tumor location and metastasis. The $\mathrm{G}$ test was performed to demonstrate the association between the variables.

\section{Results}

The HL cases diagnosed at Ophir Loyola Hospital were distributed among the states of Piauí (1 case), Maranhão (2 cases), Amapá (15 cases), and Pará (318 cases) (Fig. 1).

The only case in Piauí state came from the capital, Teresina. The cases in Maranhão state came from Imperatriz and Maranhãozinho cities. Most cases in the state of Amapá came from its capital, Macapá (13 cases). The cases in Pará state were widely distributed among its cities; hence, the majority of cases came from the metropolitan regions: Belém - the capital of Pará - (128 cases), Ananindeua (39 cases), and Castanhal city (15 cases) (Fig. 2).

In descending order, the frequency of HL subtype was: NSHL (65\%); MCHL (22\%); LDHL (6\%); LRHL (4\%); NLPHL (3\%). The HL cases are most commonly diagnosed in males (60\%). The frequency of HL subtypes, most commonly diagnosed in males was: $62 \%$ for NSHL; $55 \%$ for MCHL; $45 \%$ for LDHL; $58 \%$ for LRHL; $64 \%$ for NLPHL (Table 1). 
Table 1

- Distribution of cases of Hodgkin's lymphoma by tumor primary location and gender.

\begin{tabular}{|c|c|c|c|c|c|c|c|c|c|c|c|c|c|c|}
\hline \multirow{2}{*}{\multicolumn{2}{|c|}{ Histological types }} & \multirow[t]{2}{*}{$\begin{array}{l}\text { Teste/ } \\
\text { p-valor }\end{array}$} & \multicolumn{2}{|c|}{$\begin{array}{l}\text { Nodular } \\
\text { sclerosis } \\
\text { Hodgkin's } \\
\text { Lymphoma }\end{array}$} & \multicolumn{2}{|c|}{$\begin{array}{l}\text { Mixed } \\
\text { cellularity } \\
\text { Hodgkin's } \\
\text { Lymphoma }\end{array}$} & \multicolumn{2}{|c|}{$\begin{array}{l}\text { Lymphocyte- } \\
\text { depleted } \\
\text { Hodgkin's } \\
\text { Lymphoma }\end{array}$} & \multicolumn{2}{|c|}{$\begin{array}{l}\text { Lymphocyte- } \\
\text { rich } \\
\text { Hodgkin's } \\
\text { Lymphoma }\end{array}$} & \multicolumn{2}{|c|}{$\begin{array}{l}\text { Nodular } \\
\text { lymphocyte- } \\
\text { predominant } \\
\text { Hodgkin's } \\
\text { Lymphoma }\end{array}$} & \multicolumn{2}{|c|}{ Total } \\
\hline & & & $F$ & $\%$ & $f$ & $\%$ & $f$ & $\%$ & $\mathbf{F}$ & $\%$ & f & $\%$ & $f$ & $\%$ \\
\hline \multirow{10}{*}{$\begin{array}{l}\text { Tumor } \\
\text { primary } \\
\text { location }\end{array}$} & $\begin{array}{l}\text { Cervical lymph } \\
\text { nodes }\end{array}$ & \multirow{10}{*}{$\begin{array}{l}\text { Test G } \\
(5 \% ; \\
\mathrm{Gl}= \\
36)= \\
46,45 / \\
\mathrm{p}= \\
0,1138\end{array}$} & 145 & $67 \%$ & 48 & $68 \%$ & 11 & $58 \%$ & 7 & $58 \%$ & 9 & $82 \%$ & 220 & $65 \%$ \\
\hline & Mediastinum & & 18 & $8 \%$ & 7 & $10 \%$ & 5 & $26 \%$ & 2 & $17 \%$ & 0 & $0 \%$ & 32 & $10 \%$ \\
\hline & $\begin{array}{l}\text { Inguinal and lower } \\
\text { limb lymph nodes }\end{array}$ & & 24 & $11 \%$ & 3 & $4 \%$ & 1 & $5 \%$ & 0 & $0 \%$ & 0 & $0 \%$ & 28 & $8 \%$ \\
\hline & $\begin{array}{l}\text { Axillary and upper } \\
\text { limb lymph nodes }\end{array}$ & & 19 & $9 \%$ & 3 & $4 \%$ & 1 & $5 \%$ & 1 & $8 \%$ & 0 & $0 \%$ & 24 & $7 \%$ \\
\hline & $\begin{array}{l}\text { Hematopoietic and } \\
\text { Reticuloendothelial } \\
\text { System }\end{array}$ & & 2 & $1 \%$ & 3 & $4 \%$ & 0 & $0 \%$ & 2 & $17 \%$ & 2 & $18 \%$ & 9 & $3 \%$ \\
\hline & $\begin{array}{l}\text { Multiple regions } \\
\text { lymph nodes }\end{array}$ & & 2 & $1 \%$ & 4 & $6 \%$ & 0 & $0 \%$ & 0 & $0 \%$ & 0 & $0 \%$ & 6 & $2 \%$ \\
\hline & $\begin{array}{l}\text { Intra-abdominal } \\
\text { lymph nodes }\end{array}$ & & 3 & $1 \%$ & 2 & $3 \%$ & 0 & $0 \%$ & 0 & $0 \%$ & 0 & $0 \%$ & 5 & $1 \%$ \\
\hline & $\begin{array}{l}\text { Intra-thoracic } \\
\text { lymph nodes }\end{array}$ & & 1 & $0 \%$ & 0 & $0 \%$ & 1 & $5 \%$ & 0 & $0 \%$ & 0 & $0 \%$ & 2 & $1 \%$ \\
\hline & Retroperitoneum & & 1 & $0 \%$ & 1 & $1 \%$ & 0 & $0 \%$ & 0 & $0 \%$ & 0 & $0 \%$ & 2 & $1 \%$ \\
\hline & Other regions & & 5 & $2 \%$ & 2 & $3 \%$ & 1 & $5 \%$ & 0 & $0 \%$ & 0 & $0 \%$ & 8 & $2 \%$ \\
\hline \multirow[t]{2}{*}{ Gender } & Male & $\begin{array}{l}\text { Test G } \\
(5 \% ; \\
\mathrm{GI}=4) \\
= \\
3,16 /\end{array}$ & 137 & $62 \%$ & 40 & $55 \%$ & 9 & $45 \%$ & 7 & $58 \%$ & 7 & $64 \%$ & 200 & $60 \%$ \\
\hline & Female & $\begin{array}{l}3,16 / \\
p= \\
0,5311\end{array}$ & 83 & $38 \%$ & 33 & $45 \%$ & 11 & $55 \%$ & 5 & $42 \%$ & 4 & $36 \%$ & 136 & $40 \%$ \\
\hline \multicolumn{2}{|c|}{ Total of cases } & & 220 & $65 \%$ & 73 & $22 \%$ & 20 & $6 \%$ & 12 & $4 \%$ & 11 & $3 \%$ & 336 & $100 \%$ \\
\hline
\end{tabular}

The primary tumor location was predominant in nodal regions, such as cervical lymph nodes (65\%), mediastinum (10\%), inguinal and lower limb lymph nodes (8\%), and axillary and upper limb lymph nodes (7\%). The primary tumor location, regarding HL subtypes, showed that cervical lymph nodes were affected in $67 \%$ of NSHL cases, $68 \%$ of MCHL, $58 \%$ of LDHL, $58 \%$ of LRHL, and $82 \%$ of NLPHL (Table 1 ).

The patients' age showed high coefficients of variability. Due to this factor, patients' ages were analyzed with mean and median. The mean/median age, concerning HL subtype, was 25/22 years old for NSHL, 25/20 years old for MCHL, 32/21 years old for LDHL, 28/25 years old for LRHL, and 19/14 years old for NLPHL (Table 2). 
Table 2

Distribution of histological types of Hodgkin's lymphoma by age. (SD) standard deviation; (CV) coefficient of variation; (Cl) confidence

\begin{tabular}{|c|c|c|c|c|c|c|c|c|c|c|}
\hline Histological types & $\begin{array}{l}\text { Number } \\
\text { of cases }\end{array}$ & Mean & SD & $\mathrm{CV}_{\%}$ & $\begin{array}{l}\mathrm{Cl} \\
\text { (mean; } \\
\mathrm{t}(\mathrm{n}-1) ; 5 \%)\end{array}$ & Median & Minimum & Maximum & $\begin{array}{l}\text { Percentile } \\
25\end{array}$ & $\begin{array}{l}\text { Percentile } \\
75\end{array}$ \\
\hline $\begin{array}{l}\text { Nodular sclerosis } \\
\text { Hodgkin's } \\
\text { Lymphoma }\end{array}$ & 220 & 24.80 & 13.80 & $56 \%$ & $\begin{array}{l}{[23,0 ;} \\
26,6]\end{array}$ & 22.0 & 4 & 84 & 16.0 & 32.0 \\
\hline $\begin{array}{l}\text { Mixed cellularity } \\
\text { Hodgkin's } \\
\text { Lymphoma }\end{array}$ & 73 & 25.10 & 16.90 & $67 \%$ & $\begin{array}{l}{[21,2 ;} \\
29,0]\end{array}$ & 20.0 & 5 & 67 & 13.0 & 38.0 \\
\hline $\begin{array}{l}\text { Lymphocyte- } \\
\text { depleted Hodgkin's } \\
\text { Lymphoma }\end{array}$ & 20 & 32.00 & 25.80 & $81 \%$ & $\begin{array}{l}{[19,9 ;} \\
44,1]\end{array}$ & 21.5 & 6 & 79 & 8.5 & 53.5 \\
\hline $\begin{array}{l}\text { Lymphocyte-rich } \\
\text { Hodgkin's } \\
\text { Lymphoma }\end{array}$ & 12 & 28.30 & 17.20 & $61 \%$ & {$[17,4 ; 39,2]$} & 25.5 & 7 & 58 & 13.3 & 44.5 \\
\hline $\begin{array}{l}\text { Nodular } \\
\text { lymphocyte- } \\
\text { predominant } \\
\text { Hodgkin's } \\
\text { Lymphoma }\end{array}$ & 11 & 19.20 & 12.30 & $64 \%$ & $\begin{array}{l}{[10,9 ;} \\
27,5]\end{array}$ & 14.0 & 7 & 47 & 10.0 & 28.0 \\
\hline
\end{tabular}

Variables related to ethnicity, family history of cancer, tobacco and alcohol consumption were respectively $36 \%$ brown, $24 \%$ with family history of cancer, $41 \%$ never used tobacco and $19 \%$ alcohol. However, the lack of information on these variables made this analysis difficult (Table 3). 
Table 3

Distribution of histological types of Hodgkin's lymphoma by Ethnicity, risk factors and metastasis.

\begin{tabular}{|c|c|c|c|c|c|c|c|c|c|c|c|c|c|c|}
\hline \multirow{2}{*}{\multicolumn{2}{|c|}{ Histological types }} & \multirow[t]{2}{*}{$\begin{array}{l}\text { Teste/ } \\
\text { p-valor }\end{array}$} & \multicolumn{2}{|c|}{$\begin{array}{l}\text { Nodular } \\
\text { sclerosis } \\
\text { Hodgkin's } \\
\text { Lymphoma }\end{array}$} & \multicolumn{2}{|c|}{$\begin{array}{l}\text { Mixed } \\
\text { cellularity } \\
\text { Hodgkin's } \\
\text { Lymphoma }\end{array}$} & \multicolumn{2}{|c|}{$\begin{array}{l}\text { Lymphocyte- } \\
\text { depleted } \\
\text { Hodgkin's } \\
\text { Lymphoma }\end{array}$} & \multicolumn{2}{|c|}{$\begin{array}{l}\text { Lymphocyte- } \\
\text { rich } \\
\text { Hodgkin's } \\
\text { Lymphoma }\end{array}$} & \multicolumn{2}{|c|}{$\begin{array}{l}\text { Nodular } \\
\text { lymphocyte- } \\
\text { predominant } \\
\text { Hodgkin } \\
\text { Lymphoma }\end{array}$} & \multicolumn{2}{|c|}{ Total } \\
\hline & & & $f$ & $\%$ & $f$ & $\%$ & $f$ & $\%$ & $f$ & $\%$ & f & $\%$ & $f$ & $\%$ \\
\hline \multirow[t]{5}{*}{ Ethnicity } & Brown & \multirow{5}{*}{$\begin{array}{l}\text { Test G } \\
(5 \% ; \mathrm{Gl} \\
=8)= \\
6,58 / \\
p= \\
0,5829\end{array}$} & 84 & $38 \%$ & 21 & $29 \%$ & 6 & $30 \%$ & 6 & $50 \%$ & 4 & $36 \%$ & 121 & $36 \%$ \\
\hline & White & & 18 & $8 \%$ & 6 & $8 \%$ & 1 & $5 \%$ & 1 & $8 \%$ & 1 & $9 \%$ & 27 & $8 \%$ \\
\hline & Indigenous & & 2 & $1 \%$ & 0 & $0 \%$ & 0 & $0 \%$ & 0 & $0 \%$ & 1 & $9 \%$ & 3 & $1 \%$ \\
\hline & Black & & 2 & $1 \%$ & 2 & $3 \%$ & 0 & $0 \%$ & 0 & $0 \%$ & 1 & $9 \%$ & 5 & $1 \%$ \\
\hline & Others* & & 114 & $52 \%$ & 44 & $60 \%$ & 13 & $65 \%$ & 5 & $42 \%$ & 4 & $36 \%$ & 180 & $54 \%$ \\
\hline \multirow{3}{*}{$\begin{array}{l}\text { Familiar } \\
\text { cancer } \\
\text { history }\end{array}$} & Yes & \multirow{3}{*}{$\begin{array}{l}\text { Test G } \\
(5 \% ; \mathrm{Gl} \\
=4)= \\
5,81 / \\
p= \\
0,2141\end{array}$} & 51 & $23 \%$ & 17 & $23 \%$ & 7 & $35 \%$ & 3 & $25 \%$ & 4 & $36 \%$ & 82 & $24 \%$ \\
\hline & No & & 41 & $19 \%$ & 10 & $14 \%$ & 3 & $15 \%$ & 1 & $8 \%$ & 0 & $0 \%$ & 55 & $16 \%$ \\
\hline & Others $^{*}$ & & 128 & $58 \%$ & 46 & $63 \%$ & 10 & $50 \%$ & 8 & $67 \%$ & 7 & $64 \%$ & 199 & $59 \%$ \\
\hline \multirow{4}{*}{$\begin{array}{l}\text { Tobacco } \\
\text { consumption }\end{array}$} & Never & \multirow{2}{*}{$\begin{array}{l}\text { Test G } \\
(5 \% ; \mathrm{Gl} \\
=8)= \\
12,25 / \\
\mathrm{p}= \\
0,1406\end{array}$} & 97 & $44 \%$ & 20 & $27 \%$ & 8 & $40 \%$ & 5 & $42 \%$ & 7 & $64 \%$ & 137 & $41 \%$ \\
\hline & Consumer & & 24 & $11 \%$ & 13 & $18 \%$ & 3 & $15 \%$ & 1 & $8 \%$ & 0 & $0 \%$ & 41 & $12 \%$ \\
\hline & $\begin{array}{l}\text { Ex- } \\
\text { consumer }\end{array}$ & & 19 & $9 \%$ & 6 & $8 \%$ & 1 & $5 \%$ & 2 & $17 \%$ & 0 & $0 \%$ & 28 & $8 \%$ \\
\hline & Others $^{*}$ & & 80 & $36 \%$ & 34 & $47 \%$ & 8 & $40 \%$ & 4 & $33 \%$ & 4 & $36 \%$ & 130 & $39 \%$ \\
\hline \multirow{4}{*}{$\begin{array}{l}\text { Alcohol } \\
\text { consumption }\end{array}$} & Never & \multirow{4}{*}{$\begin{array}{l}\text { Test G } \\
(5 \% ; \mathrm{Gl} \\
=8)= \\
4,55 / \mathrm{p} \\
= \\
0,8042\end{array}$} & 46 & $21 \%$ & 8 & $11 \%$ & 3 & $15 \%$ & 3 & $25 \%$ & 3 & $27 \%$ & 63 & $19 \%$ \\
\hline & $\begin{array}{l}\text { Ex- } \\
\text { consumer }\end{array}$ & & 14 & $6 \%$ & 3 & $4 \%$ & 0 & $0 \%$ & 1 & $8 \%$ & 0 & $0 \%$ & 18 & $5 \%$ \\
\hline & Consumer & & 11 & $5 \%$ & 2 & $3 \%$ & 0 & $0 \%$ & 1 & $8 \%$ & 1 & $9 \%$ & 15 & $4 \%$ \\
\hline & Others* & & 149 & $68 \%$ & 60 & $82 \%$ & 17 & $85 \%$ & 7 & $58 \%$ & 7 & $64 \%$ & 240 & $71 \%$ \\
\hline \multirow[t]{2}{*}{ Metastasis } & Without & \multirow{2}{*}{$\begin{array}{l}\text { Test G } \\
(5 \% ; \mathrm{Gl} \\
=4)= \\
11,06 / \\
p= \\
0,0259\end{array}$} & 218 & $99 \%$ & 71 & $97 \%$ & 18 & $90 \%$ & 12 & $100 \%$ & 9 & $82 \%$ & 328 & $98 \%$ \\
\hline & $\begin{array}{l}\text { With } \\
\text { metastasis }\end{array}$ & & 2 & $1 \%$ & 2 & $3 \%$ & 2 & $10 \%$ & 0 & $0 \%$ & 2 & $18 \%$ & 8 & $2 \%$ \\
\hline \multicolumn{3}{|l|}{ Total de cases } & 220 & $65 \%$ & 73 & $22 \%$ & 20 & $6 \%$ & 12 & $4 \%$ & 11 & $3 \%$ & 336 & $100 \%$ \\
\hline
\end{tabular}

There was no association between HL subtype and gender, primary tumor location, ethnicity, family history of cancer, tobacco consumption, alcohol consumption. The HL subtypes were associated only with metastasis, being the highest frequency of HL patients without metastasis (98\%). Metastasis was more frequent in NLPHL subtype (18\%) (Table 3). 
Our study verified that the most frequent HL subtypes were Nodular Sclerosis (65\%) and Mixed Cellularity (22\%). Some studies report that these types of LH are more frequent in western countries, such as Brazil, and corroborate the results found in the region of this study.(10, 11). The MCHL appears to be prevalent in Eastern countries (12), this heterogeneity of histological types may be related to the various aspects that involve the pathogenesis of $\mathrm{HL}$ and the etiological role of Epstein-Bar virus (EBV) infection (13).

Some patterns for HL have already been described and it is observed that these patterns generally vary according to the population's socioeconomic level and regional development. In pattern 1, reported in developing countries and in patients of low socioeconomic status, demonstrates incidence peaks of HL in early childhood with Mixed cellularity subtype and positive EBV (14).

In pattern 2, reported in countries with transitional economies, demonstrates a relatively equal frequency between MCHL and NSHL. In pattern 3: reported in developed countries and in patients of higher socioeconomic status, reveals incidence peaks of HL in the third decade of life, with a predominance of NSHL subtype and negative EBV (14).

In this study, LHEN was the most frequent and tends to follow the pattern 3 that occurs in developed countries. However, in the region of this research there was a higher occurrence of $\mathrm{HL}$ in young adults. In addition, the EBV positivity rate in the region is high, reaching $79 \%$ for the EBV EBER 1 gene (15). These findings reinforce the diversity of factors that can influence the pathogenesis of the disease, considering the particularities of each region.

Thus, it was found that $\mathrm{HL}$ in this region is more frequent in young adults (average of 26 years old) and male (60\%). According to the National Cancer Institute (INCA) of Brazil, LH can occur in any age group; however, it is more likely to affect male adolescents and young adults.(16).

Here does not seem to be a specific factor that can justify the greater involvement of males, but an important aspect related to sex is that siblings of the same sex as patients diagnosed with $\mathrm{HL}$ are 10 times more at risk of developing a disease (17). There is a possibility that same-sex siblings, especially male siblings, may have a higher incidence of Hodgkin's lymphoma due to inherited genes and infections-like exposures during childhood, which make them more susceptible to HL (18).

In this study, the individual's gender seems to be predominantly male for all histological types, therefore, there was no statistically significant difference for this variable, despite this, studies report that in some regions the NSHL affects young women in a greater proportion (10); (19).

The primary tumor location in this study was more common in cervical lymph nodes (65\%) and mediastinum (10\%) and there was no statistically significant difference between histological types. Corroborating this, research carried out at the Iraq Oncology Center found that $\mathrm{HL}$ affects cervical and mediastinal lymph nodes more frequently (10). Another study also shows that about two thirds of cases of HL have cervical lymphadenopathy HL rarely has extranodal involvement, which commonly affects extranodal organs, such as skin, bones and gastrointestinal tract (20).

There are some possibilities for these results, the first is the concentration of lymph nodes in the cervical region that may justify the major occurrence of the primary tumor in that location. It is estimated that about 300 lymph nodes in our body are located in the neck region, this represents approximately one third of all lymph nodes in our body (21).

Another possibility is characterized by the functionality of the cervical lymph nodes to fight microorganisms that try to enter the body through the nose or mouth, The oropharyngeal epithelium is the primary replication site of the EBV, which multiplies in B cells and can cause infectious mononucleosis (MI) or being able to maintain latency and can remain in this state for the life of the individual (22). The replication site may be related to the primary tumor sites, contributing to the lymph nodes in these regions being the most affected.

There was no statistically significant difference between the histological types of HL and the variables ethnicity, smoking, alcoholism. However, the lack of information in the medical records about these variables made the analysis difficult, including for $\mathrm{HL}$ in general, and makes the discussion impossible.

Thus, the expressive quantity of medical records that did not have information on the variables described above draws attention to the problem that some studies have been reporting on the low quality of health records in Brazil (23); (24).

Medical records are instruments of great importance to the management, teaching and research processes, as their information mainly contributes to the planning of health actions. Thus, it is necessary to encourage the improvement of the quality of the record of medical records (electronic or manual), so that there is no compromise in the scientific process, evaluations, implementations and monitoring of these actions (24)

Page 7/12 
Our study verified that a considerable number of metastasis cases (18\%), focuses on the NLPHL subtype. A recent study observed that most patients diagnosed with NLPHL have slow lymphadenopathies growth and rare extranodal involvement. Thus, these NLPHL characteristics can contribute to late diagnosis and a considerable number of metastases cases (14).

The NPLHL is a rare HL subtype, so the difficulty in diagnosis and specific treatment can contribute to a poor prognosis and, consequently, to metastasis, death, and disease in progression (21). In addition, the high rate of EBV positivity at Pará state (22) can impact negatively on a worse HL prognosis. The EBV presence promotes a greater production of cytokines virus-associated, which can aggravate patients' prognosis (23)

The cases of LH motivated in this study came from the states of Piauí (1 case); Maranhão (2 cases); Amapá (15 cases) and Pará (318 cases). The majority of cases are concentrated in the metropolitan region of Belém, capital of the state of Pará. The large number of cases in this region probably owes the location of the hospita I in this study, which is located in the metropolitan region of Belém. main health network reference for cancer diagnosis and treatment in the State, causing many patients to migrate to a metropolitan region in search of specialized care (9)

Our study highlights the number of cases (15 cases) from another state, the state of Amapá. The capital of Amapá is the city of Macapá, which is $331 \mathrm{~km}$ from the city of Belém. In addition to the geographic proximity between these capitals, an analysis of public accounts released by the Federal Council of Medicine showed that the city of Macapá is the capital with the least investment in health per person in Brazil (27).

In addition, according to the National Register of Health Facilities, the state of Amapá does not have a public hospital of reference for cancer treatment. Cancer patients are treated only in an oncology sector - Unit of High Oncological Complexity of Hospital das Clínicas Alberto Lima (HCAL) (28).

These factors can lead patients who need cancer treatment services in the state of Amapá to migrate to neighboring regions that offer a Center for High Complexity in Oncology, such as Hospital Ophir Loyola (9).

\section{Conclusions}

The HL and its histological types have a variety of epidemiological scenarios that can vary according to location, population studied and level of development in the region.

It was found that $\mathrm{HL}$ in the region of this study, is more frequent in young adult males, from the metropolitan region of Belém and without metastases when starting treatment. The most frequent histological type was NSHL and the one with the most cases of metastasis was NLPHL. The primary location of the tumor was predominant in cervical lymph nodes.

These results can provide the public authorities with the knowledge to adopt preventive policies, such as health education methods to alert the population and the location most affected about the disease and its symptoms, in order to make early diagnoses.

From the results, it was still possible to identify the relevance of the number of patients from the state of Amapá, highlighting the need to analyze the health scenario available to this population. In addition, the results allow comparisons with other regions in an attempt to better understand the complexity and epidemiological diversity of LH and its histological types.

This research analyzes some characteristics of $\mathrm{HL}$ in the studied region, with the need for new studies that consider a greater population diversity and a greater number of variables, also considering regional particularities, such as the impact of positivity for EBV.

\section{Abbreviations}

HL: Hodgkin's lymphoma

NHL: Non-Hodgkin's lymphoma

EBV: Epstein Barr Virus

cHL: Classic Hodgkin's Lymphoma

OLH: Ophir Loyola Hospital 
HRS: Hodgkin and Reed-Sternberg cells

NSHL: Hodgkin's Lymphoma, Classic Nodular Sclerosis

MCHL - Classic Mixed Cellular Hodgkin's Lymphoma

LDHL - Classic Hodgkin's Lymphoma Lymphocytic Depletion

LRHL - Classic Hodgkin's Lymphoma Rich in Lymphocytes

NLPHL - Hodgkin's Lymphoma Nodular Lymphocytic Predominance

WHO - World Health Organization

IBGE - Brazilian Institute of Geography and Statistics

\section{Declarations}

\section{Ethics approval and consent to participate}

This study was approved by the Research Ethics Committee of Evandro Chagas Institute (CAAE 92116618.0.0000.0019) and Ophir Loyola Hospital (CAAE 92116618.0.3001.5550).

\section{Consent for publication}

Not applicable

Availability of data and materials

All data generated or analysed during this study are included in this published article

\section{Competing interests}

The authors declare that they have no competing interests

\section{Funding}

Not applicable

\section{Authors' contributions}

All authors read and approved the final manuscript

\section{Acknowledgements}

Not applicable

\section{References}

1. Hodgkin T. Excerpts from: On Some Morbid Appearances of the Absorbent Glands and Spleen. CA Cancer J Clin. 1973;23(1):54-60.

2. Harris NL, Jaffe ES, Diebold J, Flandrin G, Muller-Hermelink HK, Vardiman J, et al. World Health Organization Classification of Neoplastic Diseases of the Hematopoietic and Lymphoid Tissues: Report of the Clinical Advisory Committee Meeting-Airlie House, Virginia, November 1997. 1999;36(3):1-8.

3. Boo YL, Ting HSY, Yap DFS, Toh SG, Lim SM. Clinical features and treatment outcomes of Hodgkin lymphoma: A retrospective review in a Malaysian tertiary hospital. Blood Res. 2019;54(3):210-7.

4. Swerdlow S, Campo E, Harris N, Jaffe E, Pileri S, Stein H, et al. WHO classification of tumours of haematopoietic and lymphoid tissues. 4th ed. Lyon, France: IARC Press; 2017.

5. Shanbhag S, Ambinder R. Hodgkin Lymphoma: a review and update on recent progress. Physiol Behav. 2017;176(1):139-48. 
6. INCA. Linfoma de Hodgkin [Internet]. 2018 [cited 2020 Mar 23]. Available from: https://www.inca.gov.br/tipos-de-cancer/linfoma-dehodgkin

7. Ansell SM. Hodgkin Lymphoma: Diagnosis and Treatment. Mayo Clin Proc. 2015;90(11):1574-83.

8. INCA. Estimativa 2020: incidência de câncer no Brasil. 2020;120 p.

9. Hospital Ophir Loyola. Hospital Ophir Loyola (HOL) [Internet]. 2020 [cited 2020 Oct 1]. Available from:

http://www.ophirloyola.pa.gov.br/content/hospital-ophir-loyola-hol

10. Shamoon R, Ali M, Shabila N. Overview and outcome of Hodgkin's Lymphoma: Experience of a single developing country's oncology centre. PLoS One. 2018;13(4):1-11.

11. Pourtsidis A, Doganis D, Baka M, Bouhoutsou D, Varvoutsi M, Synodinou M, et al. Differences between younger and older patients with childhood Hodgkin lymphoma. Pediatr Hematol Oncol. 2013;30(6):532-6.

12. Hjalgrim H. On the aetiology of Hodgkin lymphoma. Dan Med J. 2012;59(7):1-22.

13. Sherief LM, Elsafy UR, Abdelkhalek ER, Kamal NM, Elbehedy R, Hassan TH, et al. Hodgkin lymphoma in childhood. Med (United States). 2015;94(15):1-7.

14. Piris MA, Medeiros LJ, Chang KC. Hodgkin lymphoma: a review of pathological features and recent advances in pathogenesis. Pathology. 2020;52(1):154-65.

15. Monteiro TAF. Detecção do genoma do Vírus de Epstein Barr ( EBV ) em tecidos de pacientes com doença de hodgkin da região norte do Brasil. 2010;102.

16. INCA. Linfoma de Hodgkin [Internet]. 2020 [cited 2020 Mar 24]. Available from: https://www.inca.gov.br/tipos-de-cancer/linfoma-dehodgkin

17. Ansell SM. Hodgkin lymphoma: 2018 update on diagnosis, risk-stratification, and management. Am J Hematol. 2018;

18. SAC. Society American Cancer - Hodgkin Lymphoma Risk Factors [Internet]. 2018 [cited 2020 Mar 24]. Available from: https://www.cancer.org/cancer/hodgkin-lymphoma/causes-risks-prevention/risk-factors.html

19. Salati M, Cesaretti M, Macchia M, El Mistiri M, Federico M. Epidemiological overview of Hodgkin lymphoma across the Mediterranean basin. Mediterr J Hematol Infect Dis. 2014;6(1):1-10.

20. Baiocch O, Penna A. Linfoma de Hodgkin , quais as recomendações para diagnóstico e tratamento? Vol. I. 2019. p. 1-8.

21. Saleh SO. Linfonodos do nível VI: estudo anatômico dos linfonodos. Universidade de São Paulo- USP; 2016.

22. Oliveira JL De, Freitas RT, Arcuri LJ, Gomes AP, Vitorino RR, Rodrigues DC, et al. O vírus Epstein-Barr e a mononucleose infecciosa. Rev Bras Clin Med. 2012;10(6):535-43.

23. Pavão ALB, Andrade D, Mendes W, Martins M, Travassos C. Estudo de incidência de eventos adversos hospitalares, rio de janeiro, Brasil: Avaliação da qualidade do prontuário do paciente. Rev Bras Epidemiol. 2011;14(4):651-61.

24. Almeida MM, Macedo WBS, Azevedo CAS, Pessoa RMC. Quality of nursing records in pronouns of pregnant women in the family health strategy: an integrative review of the literature. Reon Facema. 2017;3(3):649-58.

25. Savage KJ, Mottok A, Fanale M. Nodular lymphocyte predominant Hodgkin lymphoma. 2016;

26. Chang KC, Chen PCH, Chang Y, Wu YH, Chen YP, Lai CH, et al. Epstein-Barr virus latent membrane protein-1 up-regulates cytokines and correlates with older age and poorer prognosis in Hodgkin lymphoma. Histopathology. 2017;70(3):442-55.

27. CFM. Conselho Federal de Medicina - Macapá é a capital com menor investimento em saúde por pessoa do país [Internet]. 2018 [cited 2020 Mar 24]. Available from: https://g1.globo.com/ap/amapa/noticia/2018/11/14/macapa-e-a-capital-com-menor-investimento-emsaude-por-pessoa-do-pais-aponta-cfm.ghtml

28. CNES. Estabelecimentos de Saúde no Brasil [Internet]. 2020. Available from: http://cnes.datasus.gov.br/pages/estabelecimentos/ficha/quimio-radio/1600302020645

\section{Figures}




\section{- o.}

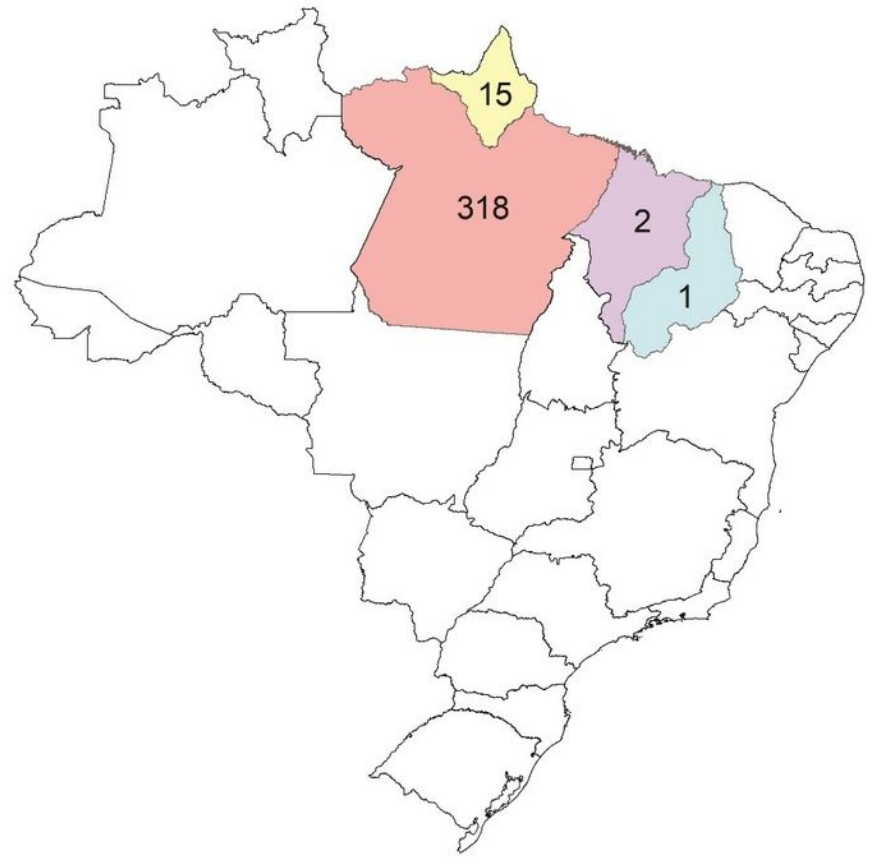

\section{HL cases by Brazil's states}

AMAPÁ - NSHL (9); MCHL (5); LDHL (1)

MARANHÃO - NSHL (1); MCHL (1)

PARÁ - NSHL (209); MCHL (67); LDHL (19); LRHL (12); NLPHL (11)

PIAUI - NSHL (1)

\section{Figure 1}

Spatial distribution by state of Hodgkin's Lymphoma cases. Note: The designations employed and the presentation of the material on this map do not imply the expression of any opinion whatsoever on the part of Research Square concerning the legal status of any country, territory, city or area or of its authorities, or concerning the delimitation of its frontiers or boundaries. This map has been provided by the authors. 


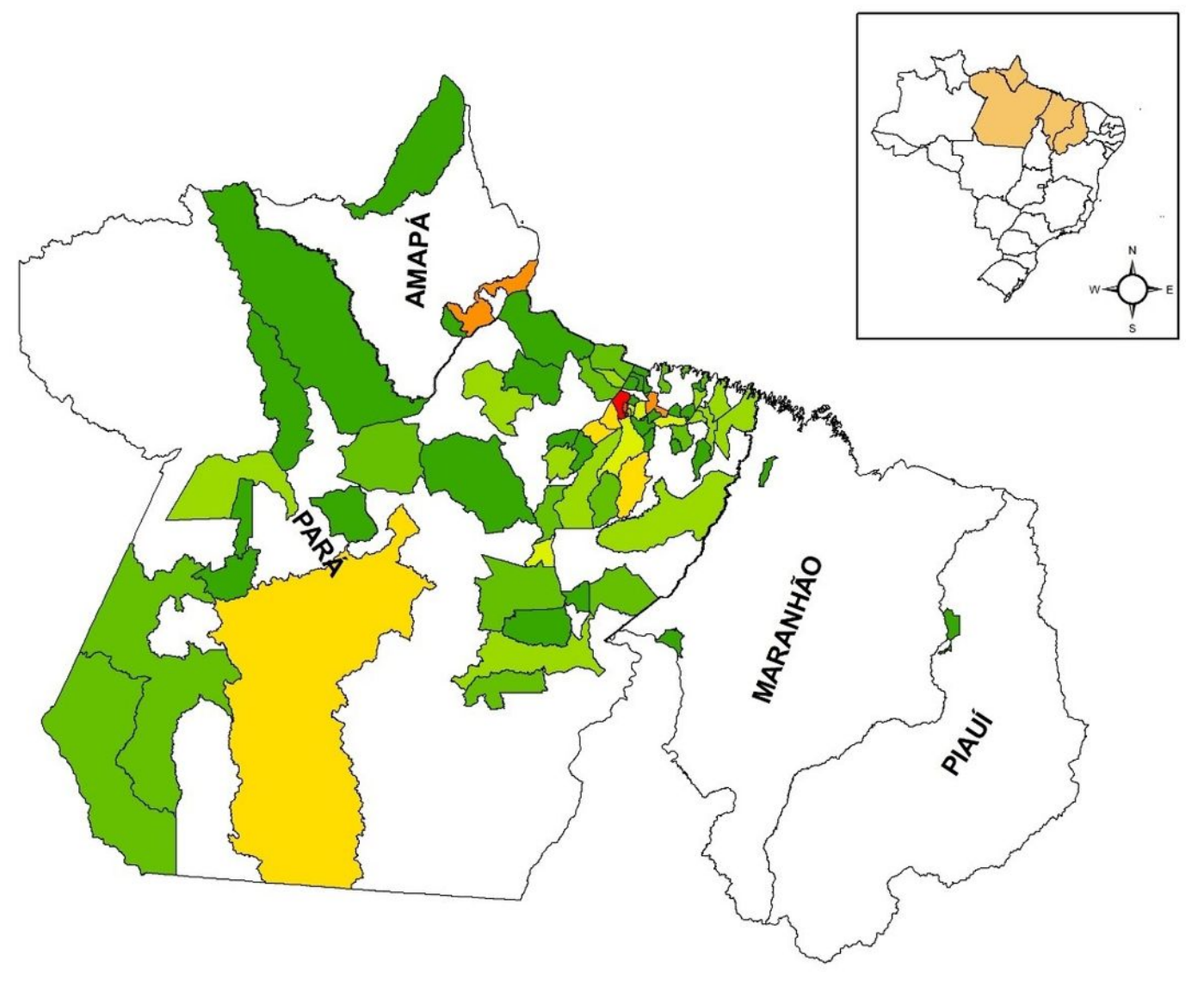

Number of cases

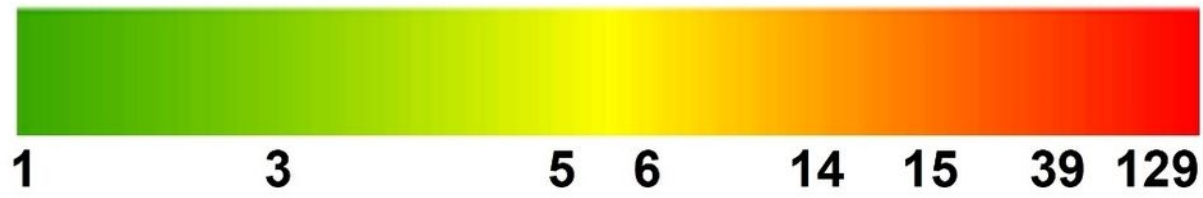

\section{Figure 2}

Hodgkin's Lymphoma cases - Spatial distribution by city. Note: The designations employed and the presentation of the material on this map do not imply the expression of any opinion whatsoever on the part of Research Square concerning the legal status of any country, territory, city or area or of its authorities, or concerning the delimitation of its frontiers or boundaries. This map has been provided by the authors. 